Thorax (1976), 31, 534.

\title{
Post-mortem studies of the semistatic volume-pressure characteristics of infants' lungs
}

\author{
D A VID G. FA G A N \\ Department of Pathology, Children's Hospital, Sheffield
}

\begin{abstract}
Fagan, D. G. (1976). Thorax, 31, 534-543. Post-mortem studies of the semistatic volumepressure characteristics of infants' lungs. Semistatic air volume-pressure (V-P) loops were recorded from 172 isolated lungs obtained from infants and children at necropsy. Technically unsatisfactory V-P loop behaviour and the presence of pathological changes led to the exclusion of 98 lungs. A further 10 lungs were excluded as it was decided to study the period of growth up to $90 \mathrm{~cm}$ crown-heel length. A total of 64 left lungs remained which were designated 'normal'. Control data were collected in an attempt to quantify the effects of storage and variations in inflation technique. A maximum inflation pressure of $+30 \mathrm{cmH}_{2} \mathrm{O}$ was used as a standard $\mathrm{P}_{\max }$. The resulting maximum inflation volume $\left(\mathrm{V}_{\max }\right)$ data showed a cubic relation to the crown-heel length which deviated from the values obtained by the use of in-vivo regression equations. The extent and pattern of the deviation suggest that the technical factors are not a major contributory cause, and other explanations are discussed.

The low-pressure proportional data from the deflation limb of the V-P curve are plotted against the crown-heel length, and the resulting curve is analysed. There is a sharp fall in the proportion of $\mathrm{V}_{\max }$ retained in the lung at $+5 \mathrm{cmH}_{2} \mathrm{O}$ and $+2.5 \mathrm{cmH}_{2} \mathrm{O}$ with increasing body length, but proportional volume at zero transpulmonary pressure follows the same growth-related pattern as $\mathrm{V}_{\max }$.
\end{abstract}

The semistatic volume-pressure (V-P) loop obtained by inflating and deflating a lung with air in steps is a well-recognized method of studying the basic pulmonary mechanics of the lung (von Neergaard, 1929; Radford, 1957; Mead, 1961).

In its simplest form, the air V-P loop is obtained by inflating and deflating the lung at fixed intervals of either volume or pressure. Time is allowed for equilibration after each change. This technique produces the semistatic loop as opposed to the dynamic loop. It is called semistatic because the stress relaxation curve of the lung is such that no sharp equilibrium point is attainable. The equilibration time of 30 seconds is assumed by most workers to give a good approximation.

The deflation limb of the dynamic V-P loop is a measure of the recoil of the lung and the flow capacity of air passages, while the semistatic loop gives a measure of the recoil force of the lung alone.

The recoil force of the lung during deflation may be divided into forces due to tissue retractive power and forces due to surface tension. The high-pressure portion of the deflation limb is thought to be controlled by tissue forces, and the low-pressure portion by surface tension forceso The measurement of the semistatic V-P loop gives. a measure of the function of both of these ele ments of the lung's retractive power.

Studies of pulmonary mechanics using thio technique are mainly performed on experimenta animals' lungs as these are the only lungs whic can be obtained under strictly controlled condi tions. This is highly desirable in order to minimize changes occurring as a result of the mode off death, the length of postmortem interval, and the्ट presence of pathological changes. There is littlo doubt that changes in V-P loop characteristics do occur as a result of the death process and pos: mortem delay. These factors have been majơs difficulties in the use of human material for the study of pulmonary mechanics by this method.

McIlroy (1952), and subsequently Mead an Collier (1959), showed that much of the variatio of results from postmortem human material coulif be attributed more to a failure of standardization 
of inflation techniques than to the use of necropsy material.

The experiments of Gribetz, Frank, and Avery (1959) showed that the semistatic V-P curve was a useful tool for studying surfactant abnormality in newborn human infants using necropsy material, while Clements, Brown, and Johnson (1958) have made extensive use of the V-P curve in the elucidation of the role of surfactant in controlling alveolar stability. Gruenwald (1961) has also carried out many inflation cycles on human infants' lungs with apparently reproducible results.

The main objectives of the present study are the examination of the deflation limbs of the semistatic V-P loops obtained from the lungs of infants up to 2 years of age (circa $90 \mathrm{~cm}$ crownheel length) to ascertain whether the same growthrelated differences occur in the human as have been reported previously in experimental animals (Agostini, 1959; Avery and Cook, 1961; Gruenwald, 1966; Havránková and Kuncová, 1971) and to quantify as far as possible the effects on the deflation limb of variations in postmortem interval and experimental technique.

\section{MATERIAL AND METHODS}

During routine necropsy the left lung or both lungs were removed from children of all ages dying from various causes at the Children's Hospital, Sheffield. The bodies had been stored at $4^{\circ} \mathrm{C}$ since death. In most cases the lungs were inflated immediately after removal, and in every case within 48 hours of death.
The lungs were not rendered airless before inflation since the lungs of older children could not be degassed without producing interstitial emphysema. Instead, they were weighed in water and in air before inflation, and the volume of air was recorded. The specific gravity of the lung tissue was assumed to be 1.062 .

Immediately before inflation, the lung was warmed to either $18^{\circ} \mathrm{C}$ or $37^{\circ} \mathrm{C}$ in a polythene bag floating in a water-bath at the appropriate temperature. Between 1 and 2 hours was allowed for the lungs to reach the required temperature, depending on the size of the lung.

The main bronchus was cannulated and the cannula was connected to the apparatus (Fig. 1). This is identical with the apparatus described by Gribetz et al. (1959) with the addition of a facility for negative-pressure inflation.

Inflation cycles were performed using predetermined pressure changes, with an equilibration time ranging between 30 seconds and 5 minutes between each pressure change. Equilibration was assumed to be complete if no change in the manometer level was seen after isolating the lung from the air source for 30 seconds. The volume was then recorded after correction to atmospheric pressure. This was done by isolating the lung and adjusting the height of the movable reservoir until the manometer read zero.

The volume of air displaced into the lung could then be read as the difference between the water level readings on the reservoir scale. This manoeuvre also corrects the displaced volume in respect of the compression of gas in the air

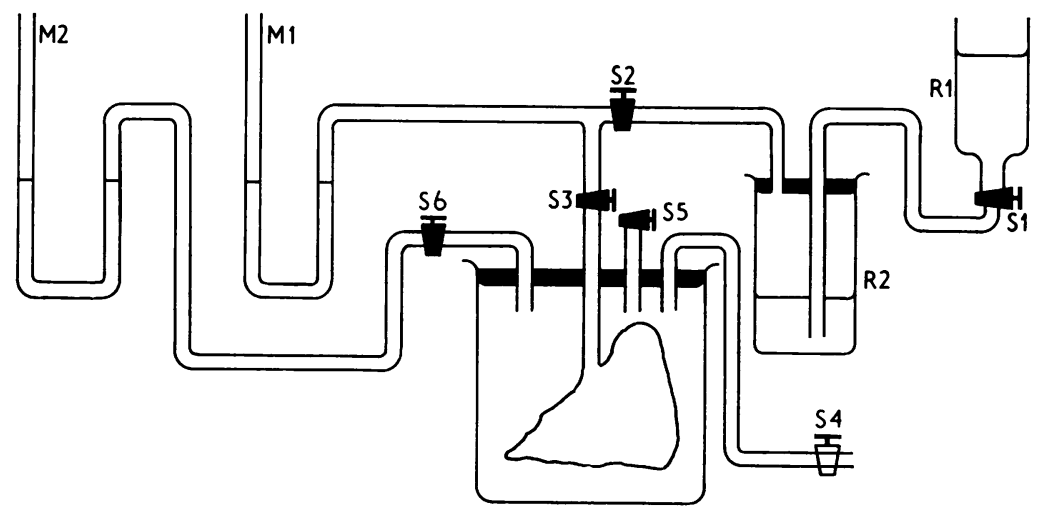

FIG. 1. The apparatus. Reservoirs $\mathrm{R} 1$ and $\mathrm{R} 2$ contain water. Water moving from $\mathrm{R} 1$ to $\mathrm{R} 2$ displaces air into the lung. Pressures are measured on manometers M1 and M2. Air flow is controlled by stopcocks S1-S6. The volume of air displaced is read from a scale on $\mathrm{R} 1$. 
reservoir, but does not correct the volume of air in the lung for compression. This correction is performed later according to Boyle's law.

During inflation cycles the lung was allowed to hang freely from the cannula exposed to ambient room temperature. Frequent spraying wi'h warmed isotonic saline was necessary to prevent the pleural surfaces from drying.

A pressure of $+30 \mathrm{cmH}_{2} \mathrm{O}$ was used as a standard maximum inflation pressure $\left(P_{\max }\right)$.

Negative-pressure inflations were carried out by simply enclosing the lung in a rigid sealed container attached to a manometer and a vacuum pump.

The same inflation and deflation procedure and equilibration times were used regardless of the use of positive or negative pressure to inflate the lung. Any lung which failed to open completely or leaked at any stage was excluded from the series.

After the V-P studies the lung was fixed, inflated with air at different pressure levels, by being floated in a closed container filled with $10 \%$ formol saline. Thin paper tissues were placed over the surface of the floating lung to prevent drying. The minimum space possible was left between the formol saline and the lid of the container. This produced adequate fixation within three days for initial block selection, and the selected blocks were post-fixed for a further 24 hours. Histological sections were then cut and examined.

Any lung which showed histological evidence of any pathological change in the lung parenchyma was excluded. Thus all cases of alveolar haemorrhage, pneumonic consolidation, infarction, fibrosis or interstitial emphysema were totally excluded. Evidence of airway obstruction or occlusion led to exclusion as did any congenital malformation of either the lung or the heart and pulmonary vasculature. Cases of respiratory distress syndrome due to surfactant deficiency were excluded along with focal pulmonary immaturity.

The remaining lungs giving satisfactory deflation data and showing none of these pathological conditions were designated 'normal'. Lungs were not excluded for oedema alone.

\section{CONTROLS}

Control experiments were carried out to assess the effects of the following variations in the preparation of the lung and experimental procedure.

Reliable determination of subtle changes in V-P loop characteristics requires far more control data in human material than in experimental animal models as one can control neither the $\stackrel{\frac{0}{0}}{\circ}$ supply of tissues nor the events preceding their $\frac{O}{O}$ availability.

The variables studied were:

1 The effects of storage at $+4^{\circ} \mathrm{C}$

2 The effect of rendering the lung airless com- $-\infty$ pared to inflating it without degassing $\vec{\circ}$

3 The temperature at which inflation was carried out $\left(18^{\circ} \mathrm{C}\right.$ or $\left.37^{\circ} \mathrm{C}\right)$

4 Supporting the lungs

5 Inflating the lungs to different maximum ${ }_{\dot{\omega}}^{\times}$ inflation pressures $\left(P_{\max }\right)$

6 Using negative pressure rather than per- $c$ bronchial positive pressure to inflate the lungs

7 The number of cycles performed.

Mcllroy (1952) noted that the lung loses airo irregularly after death, and Pattle and Burgess? (1961) have warned that the surfactant propertieso may be rapidly destroyed after death by both pathological factors and delayed or inadequatee refrigeration.

The effects of storage were subdivided into two periods, that of the delay between death and necropsy, and between necropsy and inflation studies. To study this, a series of lungs wereू stored at $4^{\circ} \mathrm{C}$ for varying lengths of time afteri necropsy. Each lung was inflated immediately after necropsy and subsequently after several days $\frac{0}{3}$ storage. The lungs were only occasionally re stored to avoid possible alterations in propertie due to repeated warming and cooling cycles.

On one occasion a lung was left at room tem perature overnight before a further inflation cycle was attempted. Autolysis had proceeded so rapidlyo that the lung immediately exhibited massive inter stitial emphysema at a remarkably low pressure? Overnight storage at room temperature renderş the lung useless for volume-pressure inflation studies.

\section{RESULTS}

The results are presented as the maximum infla tion volume $\left(\mathrm{V}_{\max }\right)$ which the lung contained wherp subjected to the maximum inflating pressures $\left(P_{\max }\right)$. Under standard conditions, $P_{\max }$ was alway $+30 \mathrm{~cm} \mathrm{H}_{2} \mathrm{O}$ but where higher maximum pressures? were used, $+40 \mathrm{cmH}_{2} \mathrm{O}$, the abbreviation $\mathrm{P}_{40}$ i used. Unless otherwise stated $P_{\max }$ is always $P_{30} \cdot{ }^{+}$

The volumes recorded during deflation are al $\frac{0}{\circ}$ ways expressed as percentages of the $\mathrm{V}_{\max }$. Fo example, at $+5 \mathrm{cmH}_{2} \mathrm{O}, \mathrm{P}_{5}$, the volume, $\mathrm{V}_{5}$, repre $\frac{\mathrm{P}}{\mathrm{D}}$ sents the expression: (Volume at $+5 \mathrm{cmH}_{2} \mathrm{O} \stackrel{8}{\circ}$ $\mathrm{V}_{\max } \times 100 \%$ ). 


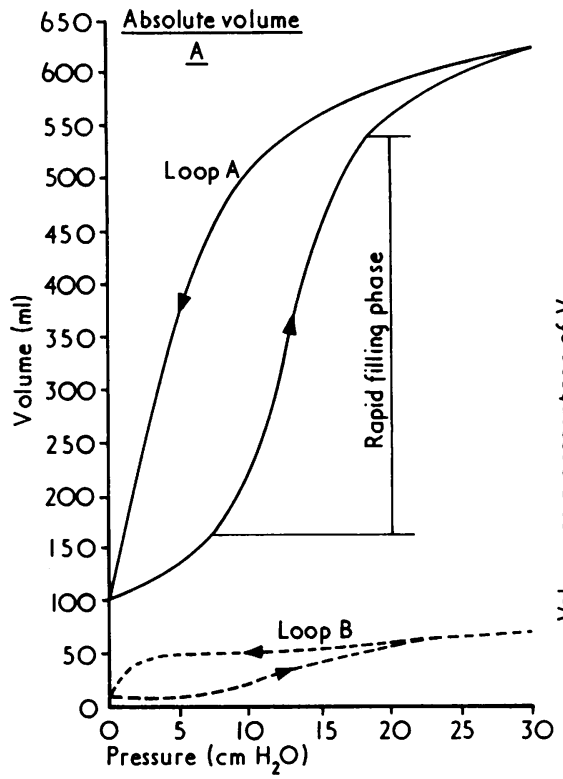

(a)

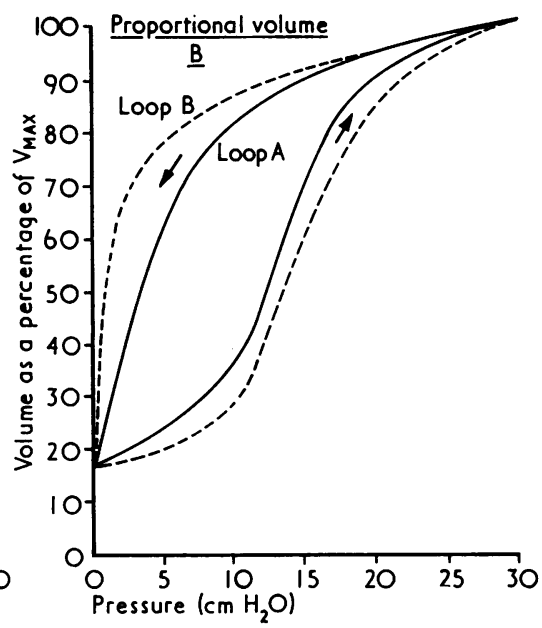

(b)

FIG. 2. The two curves on each figure are from infants of (a) $88 \mathrm{~cm}$ crown-heel length, and (b) $46 \mathrm{~cm}$ crow'n-heel length, presented in absolute volume against pressure, and proportional volume against pressure.

The volume results are expressed in this proportional manner in order to compare V-P loop deflation limbs from the lungs of widely varying capacities (Fig. 2).

It is emphasized that all volume data presented were recorded from the left lung during deflation from $V_{\max }$.

In total, 172 lungs were studied. Of these, 138 gave technically satisfactory V-P loops. A further 64 lungs were deleted from the normal series after histopathological examination, leaving 74 lungs. Of these, 64 were obtained from infants and children of less than $90 \mathrm{~cm}$ crown-heel length. These lungs constituted the normal series.

The results of alterations in technique in respect of $V_{\max }$ are shown in Table I. The results of the same alterations in technique in respect of $V_{5}$ are shown in Table II.

The results are presented as the mean differences between two successive inflation/deflation cycles with the condition changes as specified between the two cycles. The differences shown in Table II are those obtained during deflation.

In some control comparisons, conditions were held constant between the first and second cycles, and others between the second and third cycles.
T A B L E I

MAXIMUM INFLATION VOLUME $\left(\mathrm{V}_{\max }\right)$ CONTROLS

\begin{tabular}{|c|c|c|c|}
\hline Differences between & $\begin{array}{l}\text { No. of } \\
\text { Lungs }\end{array}$ & $\begin{array}{l}\text { \% Mean } \\
\text { Change } \\
\text { in } V_{\max }\end{array}$ & SD \\
\hline $\begin{array}{l}P_{\max } \text { constant } \\
\text { 1st/2nd inflation, both at } 18^{\circ} \mathrm{C} \\
\text { 1st } / 2 \text { nd, both at } 37^{\circ} \mathrm{C} \\
2 \text { nd } / 3 \mathrm{rd} \text {, regardless of temperature } \\
T\left({ }^{\circ} \mathrm{C}\right) \text { constant, } P_{\max } \text { constant } \\
\text { 1 st } / 2 \text { nd cycle, lung airless before } \\
\text { inflation } \\
2 \text { nd } / 3 \mathrm{rd} \text {, lung supported } \\
\text { Negative/positive pressure cycle } \\
T\left({ }^{\circ} \mathrm{C}\right) \mathrm{constant} \\
+30 \mathrm{cmH} \mathrm{O}_{2} \mathrm{cycle} /+40 \mathrm{cmH} \mathrm{H}_{2} \mathrm{O} \text { cycle } \\
+40 \mathrm{~cm} /+30 \mathrm{~cm} \\
+30 \mathrm{~cm} /+25 \mathrm{~cm}\end{array}$ & $\begin{array}{r}10 \\
6 \\
11 \\
17 \\
12 \\
9\end{array}$ & $\begin{array}{l}+4.4 \\
+4.0 \\
+1.8 \\
\\
+10.7 \\
+1.0 \\
+1.2 \\
+10.0 \\
+4.0 \\
-0.3\end{array}$ & $\begin{array}{l} \pm 2.9 \\
\pm 3.4 \\
\pm 1.5 \\
\\
\pm 9.1 \\
\pm 1.0 \\
\pm 3.96 \\
\pm 3.3 \\
\pm 2.1 \\
\pm 1.9\end{array}$ \\
\hline
\end{tabular}

The controls were carried out by changing the conditions for the next inflation cycle. The results are presented as the changes between the two cycles expressed as percentages of the $V_{\max }$ of the second control cycle.

Temperature at initial inflation is always $37^{\circ} \mathrm{C}$ unless otherwise stated.

The results of repeating the volume-pressures studies at different time intervals after death are shown in Figure 3.

Figure 4 shows the regression equation for crown-heel length cubed $\left(\mathrm{CH}^{3}\right)$ against the maximal inflation capacity of the left lung, $V_{\max }$. The 
T A B L E I I LOW-PRESSURE AIR-RETENTION CONTROLS

\begin{tabular}{|c|c|c|c|}
\hline Differences between & $\begin{array}{l}\text { No. of } \\
\text { Lungs }\end{array}$ & $\begin{array}{l}\% \text { Mean } \\
\text { Change } \\
\text { in } V_{5}\end{array}$ & SD \\
\hline $\begin{array}{l}P_{\max } \text { constant } \\
1 \mathrm{st} / 2 \mathrm{nd}, 18^{\circ} \mathrm{C} \\
1 \mathrm{st} / 2 \mathrm{nd}, 37^{\circ} \mathrm{C} \\
2 \mathrm{Cd} / 3 \mathrm{rd} \text {, all temps } \\
T\left({ }^{\circ} \mathrm{C}\right) \text { constant } P \max \text { constant } \\
\text { 1 st } / 2 \mathrm{nd} \text { cycle, lungs airless before } \\
\text { inflation } \\
\text { 2nd } / 3 \mathrm{rd} \text {, lungs supported } \\
\text { Negative/positive pressure cycles } \\
T\left({ }^{\circ} \mathrm{C}\right) \mathrm{constant} \\
+30 \mathrm{~cm} /+40 \mathrm{cmH}_{2} \mathrm{O} \\
+40 \mathrm{~cm} /+30 \mathrm{cmH}_{2} \mathrm{O} \\
+30 \mathrm{~cm} /+25 \mathrm{~cm} \mathrm{H}_{2} \mathrm{O}\end{array}$ & $\begin{array}{r}9 \\
6 \\
13 \\
18 \\
13 \\
14\end{array}$ & $\begin{array}{l}+2.4 \\
+1.9 \\
+0.3 \\
\\
+2.4 \\
+0.4 \\
+0.7 \\
+1.2 \\
+1.6 \\
+0.5\end{array}$ & $\begin{array}{l} \pm 2 \cdot 0 \\
\pm 1 \cdot 4 \\
\pm 1 \cdot 4 \\
\\
\pm 2 \cdot 6 \\
\pm 0 \cdot 5 \\
\pm 2 \cdot 2 \\
\pm 2 \cdot 9 \\
\pm 4 \cdot 7 \\
\pm 1 \cdot 9\end{array}$ \\
\hline
\end{tabular}

The mean change in low pressure air retention is the mean of the numerical difference between the two values obtained, since this index is already expressed as a percentage of the $V_{\mathrm{max}}$.

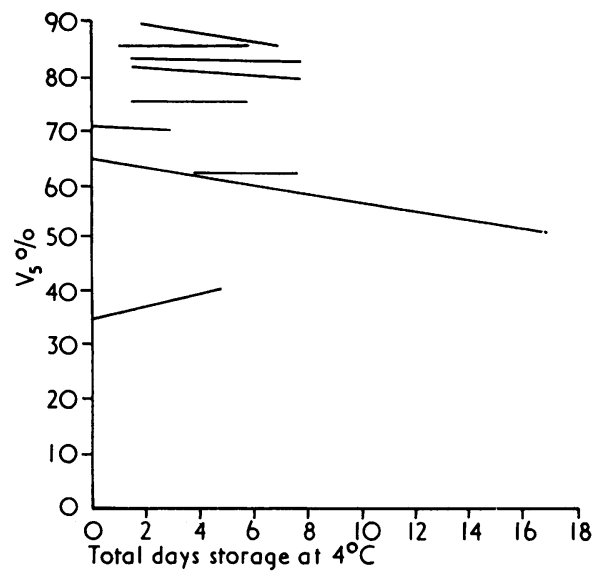

FIG. 3. The $V_{5}\left(V\right.$ at $\left.P_{5} / V_{\max } \times 100 \%\right)$ value obtained before and after storage at $4^{\circ} \mathrm{C}$ for varying time intervals. The interval between day 0 and the first inflation indicates the interval between death and the first inflation.

equation: $\mathrm{Y}=8 \mathrm{x}-25 \mathrm{ml}$, where $\mathrm{X}=\mathrm{CH}^{3} \times 10^{-4}$ and $Y=V_{\max }$ has a correlation coefficient $r=0.965$. One other correlation coefficient calculated was $\mathrm{Y}=31.1 \mathrm{~W}-6.7 \mathrm{ml}$ where $\mathrm{W}=$ body weight and $\mathrm{Y}=\mathrm{V}_{\max }$, correlation coefficient $\mathrm{r}=0.88$.

Figure 5 shows the results of plotting the proportion of $\mathrm{V}_{\max }$ remaining in the lung at +5 $\mathrm{cmH}_{2} \mathrm{O}\left(\mathrm{V}_{5}\right)$ against the crown-heel length.

Figure 6 shows the mean deflation curves obtained from the results grouped according to crown-heel length. The details of the groups are shown in Tables V and VI.

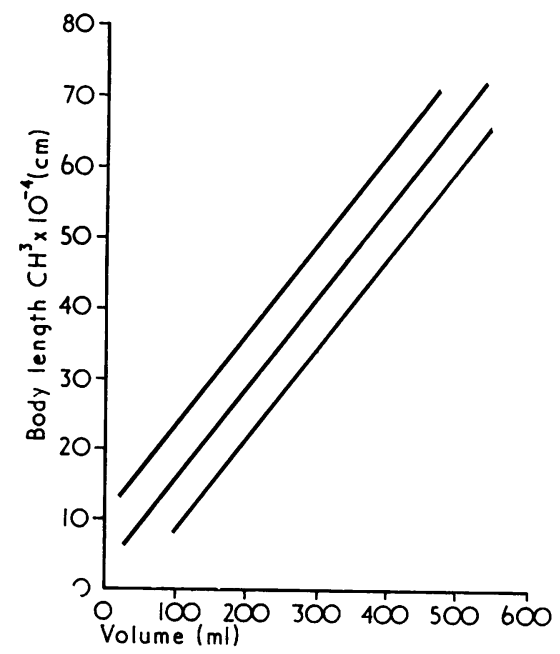

FIG. 4. The regression equation $y=8 \times \mathrm{CH}^{3} \times 10^{-4}-25$ $m l, r=0.965, \pm 2 S D$ where $y=(L)$ lung volume, $C H \stackrel{ }{=}$ crown-heel length.

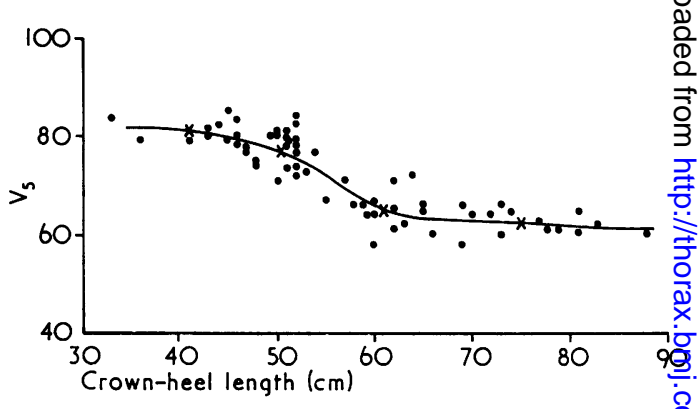

FIG. 5. The $V_{5}$ value is plotted against the crownheel length to demonstrate the change with growth. The mean points indicated are the means shown in Table $V$. The line joining these means differs from $\rightarrow a$ straight line, $\mathrm{P}<0.001$.

\section{STA'TISTICS}

Most of the lungs in the normal series were inflated by the standard technique resulting from the control studies, that is, that the second cyche was designated the index cycle, and the $P_{\max }$ wos set at $+30 \mathrm{cmH}_{2} \mathrm{O}$.

For some lungs, therefore, these variations technique required application of a correction factor to individual values; these factors afre shown (Tables III and IV). 


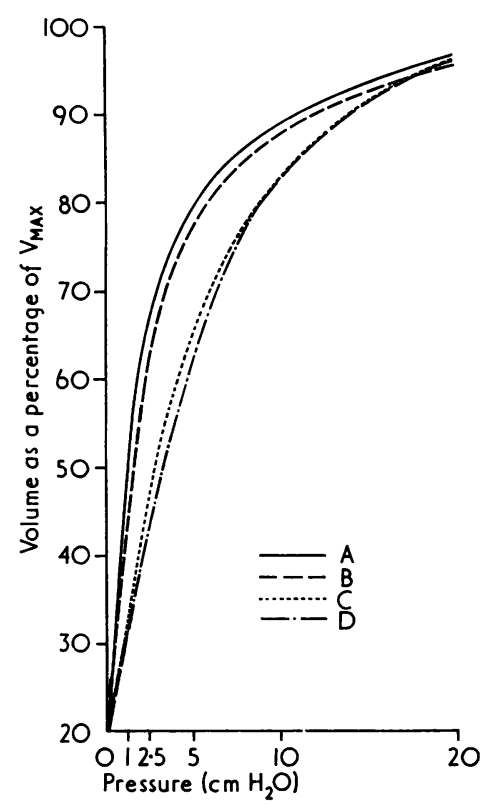

FIG. 6. The mean deflation limb curves from groups $A, B, C$, and $D$ (Table $V$ ) are shown plotted from $+20 \mathrm{cmH}_{2} \mathrm{O}$ down. The curves are virtually common between +30 and $+20 \mathrm{cmH}_{2} \mathrm{O}$, the main growthrelated changes lying between +5 and $+1 \mathrm{~cm} \mathrm{H}_{2} \mathrm{O}$. These deflation curves shift to the right with increasing stature when plotted in the proportional manner, but in absolute values the curves shift to the left.

T A B L E I I I

MAXIMAL INFLATION CORRECTION FACTORS

\begin{tabular}{l|r|cc}
\hline \multicolumn{1}{c|}{ Condition } & $\mathrm{N}$ & $\begin{array}{c}\% \text { Correction } \\
\text { (Table I) }\end{array}$ & $\begin{array}{c}\text { Variance } \\
\text { (Table I) }\end{array}$ \\
\hline 1st inflation at $18^{\circ} \mathrm{C}$ & 16 & +4.4 & \pm 8.41 \\
1st inflation at 37 & 3 & +4.0 & \pm 11.56 \\
2nd inflation (index) & 38 & -1.8 & \pm 2.25 \\
3rd inflation & 7 & -1.8 & \pm 2.0 \\
\hline
\end{tabular}

T A B L E I V

LOW PRESSURE AIR RETENTION $\left(\mathrm{V}_{5}\right)$ CORRECTION FACTORS

\begin{tabular}{l|r|cc}
\hline \multicolumn{1}{c|}{ Condition } & $\mathrm{N}$ & $\begin{array}{c}\text { \% Correction } \\
\text { (Table II) }\end{array}$ & $\begin{array}{c}\text { Variance } \\
\text { (from Table II) }\end{array}$ \\
\hline 1st inflation at $18^{\circ} \mathrm{C}$ & 16 & +2.4 & \pm 4.0 \\
1st inflation at 37 $\mathrm{C}$ & 3 & +1.9 & \pm 1.96 \\
2nd inflation (index) & 38 & -0.3 & \pm 1.96 \\
\hline 3rd inflation & 7 & -0.3 & \pm 0.9 \\
\hline
\end{tabular}

Table III sets out the required corrections for maximum inflation volume.
Table IV sets out the required corrections for low-pressure air retention.

The correction factors applied are taken from Tables I and II and the confidence interval around each individual value of all the data corrected as shown in Tables III and IV was calculated from the equation:

$$
\overline{\mathbf{S}}=\sqrt{\frac{\left(\mathrm{n}_{1}-1\right) \mathrm{S}_{1}{ }^{2}+\left(\mathrm{n}_{2}-1\right) \mathrm{S}_{2}{ }^{2}+\cdots\left(\mathrm{n}_{\mathrm{x}}-1\right) \mathbf{S}_{\mathrm{x}}{ }^{2}}{\left(\mathrm{n}_{1}-1\right)+\left(\mathrm{n}_{2}-1\right)+\cdots\left(\mathrm{n}_{\mathrm{x}}-1\right)}}
$$

Where $\overline{\mathrm{S}}=$ the mean standard deviation. The mean standard deviation for all individual $\mathrm{V}_{\max }$ values $=$ $\pm 1.65 \%$, and the mean standard deviation for all individual $V_{5}$ values, $+ \pm 1 \cdot 12 \%$. Since the standard error $=$

$$
\sqrt{\mathrm{N}_{\mathrm{c}}-1}
$$

where $\mathrm{N}_{\mathrm{c}}=$ the total number of cases, then the $95 \%$ confidence interval around each corrected individual value $= \pm 0.2 \%$ for $V_{\max }$ values and $= \pm 0.14 \%$ for $V_{5}$ values.

The data shown in Fig. 5 were examined to determine whether the mean would be best expressed as a straight line or as a curve with a form resembling the line joining the arithmetic means shown in Figure 5.

The equation: $\mathrm{V} / \mathrm{V}_{\max } \times 100 \%$ at $\mathrm{P}_{5}, \mathrm{~V}_{5},=$ $4.3575+5.2122(\mathrm{CH})-0.10691\left(\mathrm{CH}^{2}\right)+0.00063194$ $\left(\mathrm{CH}^{3}\right)$ gave the standard error of the estimate, 4.0 , where $\mathrm{CH}=$ crown-heel length. When this is compared to mean $\mathrm{V}_{5}$ value of $71.5 \%$, standard deviation of $8 \cdot 1$ (where $N=64$ ), the cubic regression equation provides a 'better' fit to the data since the standard deviation is significantly greater than the standard error of the estimate, $\mathbf{P}<0.001$.

\section{DISCUSSION}

The results from both Tables $\mathrm{I}$ and II in respect of the first cycle at either $18^{\circ} \mathrm{C}$ or $37^{\circ} \mathrm{C}$ show that the first cycle is not reproducible within acceptable limits, and that there is a big gain in reproducibility by repeating the cycle three times at $18^{\circ} \mathrm{C}$ or twice at $37^{\circ} \mathrm{C}$.

Rendering the lung airless before inflation studies is seen to be a pointless manoeuvre since it does not improve reproducibility and may cause interstitial emphysema during the degassing process, leading to wastage of material. Weighing the lung in air and water before inflation is a harmless way of estimating the initial air content of the lung. 
Supporting the lung during inflation may improve reproducibility, but curves from these lungs were already highly reproducible. It is probably worth supporting the lung if subsequent saline inflation studies are to be attempted.

The loops produced by negative-pressure inflation did not appear to differ significantly from positive-pressure inflation, and there was no worthwhile gain in reproducibility.

An important point is the effect of variations of $P_{\max }$ on the $V_{\max }$ and the low-pressure air retention. It is hardly surprising that variations of $P_{\max }$ have a profound effect on $V_{\max }$, but it is less obvious and indeed rather surprising that there is a lesser effect on the low-pressure air retention, indicated by the $V_{s}$ value.

This is highly relevant since it implies that the selection of a $P_{\max }$ value is critical when studying the changes in $V_{\max }$ related to growth, and in comparing data from other authors' communications.

On the other hand, the $P_{\max }$ value is not, within limits, a critical value in respect of $V_{5}$. Data from the other authors' series can therefore be regarded as comparable, within limits, although the $P_{\max }$ may have varied. It also means that it is not necessary, again within certain limits, to insist on a fixed $P_{\max }$ for all lung specimens, and one may use fixed-volume steps with records taken of the varying resultant pressures.

This is also important because measurement of pressure is inherently more accurate than measurement of volume when visual methods are used, especially when the volume range runs from $10 \mathrm{ml}$ to $2000 \mathrm{ml}$. If the volume is read accurately to $\pm 0.25 \mathrm{ml}$ then this represents an intrinsic error of up to $5 \%$ in the small volume range, while it is quite reasonable to measure pressure to within $\pm 0.05 \mathrm{cmH}_{2} \mathrm{O}$ giving an intrinsic error up to $1 \%$. If the investigator proceeds with fixed-volume steps, then a much greater accuracy in volume measurement is possible.

Notwithstanding the comments above, it may be necessary to use a fixed $P_{\max }$ if it is concluded that this is an essential for the aims of the project, but a lower volume accuracy may be the penalty.

In Fig. 3, the results of measuring the V-P loop at different time intervals after death are shown. Although it is claimed that surfactant remains stable for prolonged periods under refrigeration (and surfactant is thought to be the main agent controlling the low-pressure air retention), it is noticeable that there was usually a steady decline in $V_{5}$ in direct relation to the duration of storage. The observation that $V_{5}$ of the surfactant-deficient lung improved with storage is not immediateg explicable.

The effect of storage on the $\mathrm{V}_{\max }$ was irregul椐 but within the limits of variation due to the other factors described in Table $I$.

In summary, it can be seen that the two most important factors in the design of a reproducible multipurpose lung cycling procedure are the nur $\vec{G}$ ber of cycles studied (at least two, preferably threg are necessary), and the fixing of a $P_{\max }$.

The data presented in Figs 4 and 5 are limite to $90 \mathrm{~cm}$ crown-heel length in the present conjo munication. A further 10 cases up to $152 \mathrm{~cm}$ body length were studied, but although technicalf satisfactory they have not been included as the large bulk of material was from smaller infants, and more detailed studies of the whole age rang are being undertaken.

The regression equation relating $\mathrm{V}_{\max }$ to body length shows the expected high correlation with the cube of body length (Fig. 4).

When the observed mean values for $V_{\max }$ aife compared to predicted total lung capacity (TLE) values, reduced by a factor of 0.45 to compane with the present data obtained from the left lung alone, a divergent trend emerges. The predict volume of the lung $(\mathrm{L})$ in premature newborns and infants (groups A and B, Table VI) comparês well with the observed mean $\mathrm{V}_{\max }$, while the predicted values for groups $C$ and $D$ are some $20 \%$ below the mean $\mathrm{V}_{\max }$. The regression equation used was: $-\mathrm{V}=3 \times \mathrm{L}^{2 \cdot 8} \times 10^{-3}$, where $\mathrm{V}=$ total luritg capacity, and $\mathrm{L}=$ whole body length (Helliesent et al., 1958). This equation is sex independent. Although there may be some discrepancy betwee the in-vivo measurement of $\mathrm{L}$ and the measurement made at necropsy, the measurement oft necropsy is usually higher than that obtained isvivo. This should tend to reduce the differences between observed and predicted values rath than to cause them.

The regression equation of Helliesen et $\mathscr{H}^{\circ}$ (1958) was derived from data from children and young adults, over 5 years of age, but if the variog. tions were due to age differences it is both sutyprising and significant that the values are so close in premature and full-term infants but vary in the other groups.

The regression equation calculated by En: ström, Karlberg, and Kraepelien (1956) produceşa similar discrepancy between the means of the fo $\vec{Q} r$ groups and the predicted volumes, differing slight in extent but not in direction of deviation.

It seems improbable that the factor of 0.45 
applied to reduce the TLC to a figure comparable to the $\mathrm{V}_{\max }$ of the left lung could be sufficiently inaccurate to account for this difference since the partition coefficient left : right would have to increase from $0.45: 0.55$ to circa $0.7: 0.3$ to account for the observed discrepancy.

Attempts to assess whether the $V_{\max }$ results in the present series of newborn infants were comparable to the results obtained by others have proved fruitless. All other authors using isolated human lungs have not presented their data in a fashion which enables detailed comparisons to be made. In general terms, however, using figures of $\mathrm{ml} / \mathrm{kg}$ body weight or other related variables, the results do seem broadly comparable with the other authors' results in the newborn period.

The choice of a $P_{\max }$ is a critical question, since the $V_{\max }$ is obviously closely related to this value. However, volume is not uniformly related to pressure over the whole of the inflation range. In Fig. 2 , the inflation limb can be seen to consist of two phases, low and high transpulmonary pressures where the volume is not sensitive to pressure change, connected by a rapid filling phase when the volume is very sensitive to pressure change. Provided the $\mathbf{P}_{\max }$ is at a level where it is clearly in the low compliance area above the rapid filling phase, and $+30 \mathrm{cmH}_{2} \mathrm{O}$ is definitely in this area, the $V_{\max }$ is relatively insensitive to the final $\mathbf{P}_{\max }$ chosen.

This point has been well demonstrated (Salazar and Knowles, 1964, Glaister et al., 1973), and is the basis of a further possible explanation of the divergence; that is, that the pressure required to approach the asymptote of the inflation limb of the V-P loop (as defined by the use of exponential equations such as that of Salazar and Knowles (1964)) falls sharply with the growth over the 50$60 \mathrm{~cm}$ body length range. In simple terms, that a fixed $\mathrm{P}_{\max }$ of $+30 \mathrm{cmH}_{2} \mathrm{O}$ is distending the older infants' lungs to a higher point in the V-P diagram than in infants; or again, that the $P_{\max }$ required to inflate the lungs to a volume comparable to TLC in vivo falls after early infancy.

Whichever explanation is correct, the comparison between the predicted and observed $V_{\max }$ suggests that the thoracic cavity in vivo could be said to limit the lung's potential capacity beyond early infancy. More study is required to choose between these several possibilities.

The fall in $V_{5}$ between newborn and adult individuals has been reported previously in experimental animals (Agostini 1959; Avery and Cook, 1961; Gruenwald, 1966; Havránková and Kuncová, 1971) and man (Gruenwald, 1966; Fagan, 1969; Zapletal, Misur, and Samenek, 1971). Stigol, Vawter, and Mead (1972) failed to support these findings in a study which is open to criticism on three points. They examined 17 whole lungs and 10 portions of lungs obtained at necropsy from individuals ranging from a premature infant to a 23-year-old adult. Only four whole lungs were examined in the body length range of $40-60 \mathrm{~cm}$ in which the major changes in deflation limb occur (Fig. 5; Table V). Their numbers are quite inadequate to differentiate between a straight line and the expression shown above when the results all fall within the same range.

Further, all the four whole lungs as well as two of the lung portions used in this body size range would have been excluded from the present series because of significant pathological abnormalities which could very well affect the surfactant or mechanical properties of the lung (pneumonia (Pattle and Burgess, 1961); congenital heart disease (Bates and Christie, 1964; Johnson et al., 1964; Howlett, 1972)). This leaves only a portion of one lung in this body length range which might be considered normal.

Their technique varied considerably from all previous authors' work in using a $P_{\max }$ of only $+20 \mathrm{~cm} \mathrm{H}_{2} \mathrm{O}$, whereas all previous workers have

T A B L E V

RESULTS GROUPED INTO FOUR SUBGROUPS ACCORDING TO BODY LENGTH

\begin{tabular}{|c|c|c|c|c|}
\hline & $\mathbf{A}$ & B & C & D \\
\hline $\begin{array}{l}\text { Body length }(\mathrm{cm}) \\
\text { Number of cases } \\
\text { Mean gestational age (wk) } \\
\text { Mean postnatal age } \\
\text { Mean } V_{20}(\%) \\
\text { Mean } V_{10} \\
\text { Mean } V_{5} \\
\text { Mean } V_{2 \cdot 5} \\
\text { Mean } V_{1 \cdot 0} \\
\text { Mean } V_{0}\end{array}$ & $\begin{array}{c}30-45 \\
8 \\
33 \cdot 71 \pm 5 \cdot 22 \\
13 \mathrm{~d} \\
97 \cdot 0 \pm 1 \cdot 5 \\
89 \cdot 30 \pm 2 \cdot 1 \\
81 \cdot 0 \pm 2 \cdot 2 \\
71 \cdot 40 \pm 3 \cdot 7 \\
50 \cdot 90 \pm 7 \cdot 8 \\
19 \cdot 70 \pm 4 \cdot 4\end{array}$ & $\begin{array}{c}46-55 \\
26 \\
39+2 \cdot 45 \\
26 \mathrm{~d} \\
96 \cdot 20 \pm 1 \cdot 4 \\
87 \cdot 60 \pm 2 \cdot 5 \\
77 \cdot 40 \pm 4 \cdot 1 \\
61 \cdot 10 \pm 8 \cdot 4 \\
41 \cdot 10 \pm 7 \cdot 4 \\
23 \cdot 60 \pm 9 \cdot 1\end{array}$ & $\begin{array}{c}56-65 \\
15 \\
4 \cdot 4 \mathrm{mth} \\
96 \cdot 10 \pm 1 \cdot 6 \\
82 \cdot 40 \pm 4 \cdot 4 \\
65 \cdot 60 \pm 3 \cdot 8 \\
48 \cdot 30 \pm 5 \cdot 2 \\
32 \cdot 0 \pm 6 \cdot 6 \\
18 \cdot 70 \pm 7 \cdot 3\end{array}$ & $\begin{array}{c}66-90 \\
15 \\
16 \mathrm{mth} \\
96 \cdot 30 \pm 1 \cdot 5 \\
81 \cdot 70 \pm 4 \cdot 1 \\
62 \cdot 30 \pm 2 \cdot 5 \\
43 \cdot 40 \pm 4 \cdot 6 \\
32 \cdot 90 \pm 5 \cdot 0 \\
22 \cdot 20 \pm 7 \cdot 0\end{array}$ \\
\hline
\end{tabular}

The mean values for air retention during deflation are presented as percentages of the $V_{m a x}$. All ranges shown are the standard deviation. 
used between $+25 \mathrm{cmH}_{2} \mathrm{O}$ and $+40 \mathrm{cmH}_{2} \mathrm{O}$. The use of a $\mathrm{P}_{\max }$ of only $+20 \mathrm{cmH}_{2} \mathrm{O}$ gives serious problems in interpretation because, as has been discussed above, this pressure lies squarely in the range of maximum volume sensitivity to pressure. Salazar and Knowles (1964) and Glaister et al. (1973) have shown that the form of the deflation limb of the V-P loop depends largely on whether the $\mathbf{P}_{\max }$ exceeds the rapid filling phase or not. If the rapid filling phase is exceeded, the results in Tables $I$ and II in respect of $V_{\max }$ and $V_{5}$ show that increasing the $P_{\max }$ from $+30 \mathrm{~cm}$ to $+40 \mathrm{~cm}$ may increase the $V_{\max }$ by between $6 \%$ and $13 \%$, but it only produces a change of up to $4 \%$ in the $V_{5}$ value. Thus, if $P_{\max }$ exceeds the rapid filling phase, the low-pressure air retention, and therefore the form of the curve, change to a lesser degree than if the rapid filling phase is not exceeded.

The rapid fall in early postnatal life is also reflected in the $V_{2 \cdot 5}$ and $V_{1}$ values, although the rate of change between groups $A$ and $D$ (Table $V$ ) is different for each of $V_{5}, V_{2 \cdot 5}$, and $V_{1 \cdot 0}$. It would appear that the $V_{2 \cdot 5}$ value falls most, and in Table VI the $\mathrm{V}_{2.5}$ is compared to the in-vivo predicted total gas volume (TGV) at functional reserve capacity (FRC), again reduced by a factor of 0.45 to compare predicted (L) lung capacity with $\mathrm{V}_{2 \cdot 5}$ (observed).

The TGV at FRC has been calculated by substituting the mean body length and weights from groups A, B, C, and D in the regression equations of Phelan and Williams (1969), Doershuk et al. (1970), and Howlett (1972) relating to physical indices of growth, with a correlation coefficient, $r>0.92$. The predicted TGV at FRC value shown in Table VI is the mean of these equations. In Table VI, this value has been divided by the $V_{\max }$ (observed) and, to allow for any unwarranted assumption in the observed $\mathrm{V}_{\max }$ data, it has also been divided by the predicted $\mathrm{V}_{\max }$ value obtained from the combined sex regression equation of Helliesen et al. (1958).

It is notable that, using both the observed $V_{m}$ data and the predicted $V_{\max }$ data, the TGV at FRC : TGV at TLC ratio shows a similar fall bé? tween groups $A, B, C$, and $D$ and that the ratio TGV at FRC (predicted): $V_{\max }$ (observed) follows the fall in $V_{2.5}$ more closely than the $V_{5}$ or $V_{1} \cdot \omega$

In a previous communication (Fagan, 1969) the data were presented in such a form that appeared that the $\mathrm{V}_{0}$ might fall with increasing body length. Stigol et al. (1972) failed to find or correlation between body length and $V_{0}$. Table $\Psi^{D}$ shows the complete V-P data down to $V_{0}$. A negas tive phase of endobronchial pressure was not applied to these lungs, and the data shown as $V_{0}$ Table $\mathrm{V}$ refer to passive collapse lung volume onlog No convincing trend is seen relating $\mathrm{V}_{0}$ to whole body length when examined in the propor ${ }^{2}$ tional manner. It should be noted that this means that the volume of air in the lung at transputs monary pressure zero in absolute terms increas in the same fashion as the $V_{\max }$ in absolute ternis (Fig. 4). This suggests that the anatomical facto responsible for the $V_{\max }$ and $V_{0}$ differ from the factors governing the low-pressure air retentiog range, $V_{5}$ to $V_{1 \cdot 0}$.

This paper presents part of the work submitted as a MD thesis to the University of Cambridge.

Part of the work was financed by a grant from the Endowment Fund of the United Sheffield Hospitals. 후

My grateful thanks are due to Professor J. L. Emer. for his advice and encouragement, to Miss E. Swang of the Department of Biostatistics, Hospital for Sick Children, Toronto for her statistical advice, and Mr. M. Starr for the preparation of the figures.

T A B LE V I

\begin{tabular}{|c|c|c|c|c|}
\hline & $\mathbf{A}$ & B & $\mathbf{C}$ & D \\
\hline $\begin{array}{l}\text { Mean body weight }(\mathrm{kg}) \\
\text { Mean body length }(\mathrm{cm}) \\
\text { Mean } \mathrm{V}_{\max } \text { (observed) }(\mathrm{ml}) \\
\text { Mean } \mathrm{V}_{\max } \text { (predicted) }(\mathrm{ml})\end{array}$ & $\begin{array}{l}1 \cdot 69 \pm 0 \cdot 57 \\
41 \cdot 25 \pm 4 \cdot 43 \\
42 \cdot 38 \pm 15 \cdot 4 \\
45 \cdot 0\end{array}$ & $\begin{array}{r}3 \cdot 13 \pm 0 \cdot 75 \\
50 \cdot 35 \pm 2 \cdot 48 \\
79 \cdot 1 \pm 30 \cdot 9 \\
78 \cdot 7\end{array}$ & $\begin{array}{c}5 \cdot 68 \pm 1 \cdot 12 \\
61 \cdot 13 \pm 2 \cdot 42 \\
170 \cdot 1 \pm 30 \cdot 1 \\
135 \cdot 5\end{array}$ & $\begin{array}{c}9 \cdot 41 \pm 2 \cdot 72 \\
75 \cdot 33 \pm 5 \cdot 92 \\
316 \cdot 9 \pm 111 \cdot 4 \\
243 \cdot 13\end{array}$ \\
\hline Ratio mean $V_{\max } \frac{\text { predicted }}{\text { observed }}$ & 1.06 & 0.99 & 0.80 & 0.77 \\
\hline $\begin{array}{l}\text { Predicted TGV at FRC } \times 0.45(\mathrm{ml}) \\
\text { Ratio TGV at FRC: } \mathrm{V}_{\max } \text { observed } \\
\text { Ratio TGV at FRC: } V_{\max } \text { predicted } \\
\mathrm{V}_{2 \cdot 5} \text { (observed) }\end{array}$ & $\begin{array}{c}30 \cdot 5 \\
0 \cdot 72 \\
0 \cdot 68 \\
0 \cdot 71\end{array}$ & $\begin{array}{l}47 \cdot 9 \\
0 \cdot 60 \\
0 \cdot 61 \\
0 \cdot 61\end{array}$ & $\begin{array}{c}74 \cdot 4 \\
0 \cdot 44 \\
0 \cdot 55 \\
0 \cdot 48\end{array}$ & $\begin{array}{r}124 \cdot 2 \\
0 \cdot 39 \\
0 \cdot 51 \\
0 \cdot 43\end{array}$ \\
\hline
\end{tabular}

The predicted TGV at FRC value is the mean value derived from the equations of Phelan and Williams (1969), Doershuk et al. (1970), and Howlet (1972) with regression coefficients $\mathrm{r}>0.92$. The predicted $V_{\max }$ value is derived from the equation $\mathrm{V}=3 \times \mathrm{L}^{2 \cdot 8} \times 10^{-3}$ of $\mathrm{Helliesen}$ et al. (1958) reduced by a factor of 0.45 to compare with $V_{\max }$ values of the left lung. All ranges shown are the standard deviation. 


\section{REFERENCES}

Agostini, E. (1959). Volume-pressure relationships of the thorax and lung in the newborn. Journal of Applied Physiology, 14, 909.

Avery, M. E. and Cook, C. D. (1961). Volume-pressure relationships of lungs and thorax in fetal, newborn and adult goats. Journal of Applied Physiology, 16, 1034.

Bates, D. V. and Christie, R. V. (1964). Respiratory function in disease. Saunders, Philadelphia.

Clements, J. A., Brown, E. S., and Johnson, R. P. (1958). Pulmonary surface tension and the mucus lining of the lungs: some theoretical considerations. Journal of Applied Physiology, 12, 262.

Doershuk, C. F., Downs, T. D., Matthews, L. W., and Lough, M. D. (1970). A method for ventilatory measurements in subjects 1 month to 5 years of age: normal results and observations in disease. Pediatric Research, 4, 165.

Engström, I., Karlberg, P., and Kraepelien, S. (1956). Respiratory studies in children. 1. Lung volumes in healthy children 6-14 years of age. Acta Paediatrica (Uppsala), 45, 277.

Fagan, D. G. (1969). Functional development of the human lung. In The Anatomy of the Developing Lung, edited by J. L. Emery, p. 191. Heinemann, London.

Glaister, D. H., Schroter, R. C., Sudlow, M. F., and Milic-Emili, J. (1973). Bulk elastic properties of excised lungs and the effect of a transpulmonary pressure gradient. Respiration Physiology, 17, 347.

Gribetz, I., Frank, N. R., and Avery, M. E. (1959). Static volume-pressure relations of excised lungs of infants with hyaline membrane disease, newborn and stillborn infants. Journal of Clinical Investigation, 38, 2168.

Gruenwald, P. (1961). Normal and abnormal expansion of the lungs of newborn infants obtained at autopsy. Anatomical Record, 139, 471.

Gruenwald, P. (1966). Effect of age on surface properties of excised lungs. Proceedings of the Society of Experimental Biology, 122, 388.

Havránková, J. and Kuncová, M. (1971). Der Einfluss des Körpergewichtes auf die statischen Druckvolumen-Diagramme isolierter Rattenlungen. Respiration, 28, 186.

Helliesen, P. J., Cook, C. D., Friedlander, L., and Agathon, S. (1958). Studies of respiratory physiology in children. 1. Mechanics of respiration and lung volumes in 85 normal children 5-17 years of age. Pediatrics, 22, 80.

Howlett, G. (1972). Lung mechanics in normal infants and infants with congenital heart disease. Archives of Disease in Childhood, 47, 707.

Johnson, J. W. C., Permutt, S., Sipple, J. H., and Salem, E. S. (1964). Effect of intra-alveolar fluid on pulmonary surface tension properties. Journal of Applied Physiology, 19, 769.

McIlroy, M. B. (1952). The physical properties of normal lungs removed after death. Thorax, 7, 285.

Mead, J. (1961). Mechanical properties of lungs. Physiological Reviews, 41, 281.

Mead, J. and Collier, C. (1959). Relation of volume history of lungs to respiratory mechanics in anesthetized dogs. Journal of Applied Physiology, 14, 669.

von Neergaard, K. (1929). Neue Auffassungen über einen Grundbegriff der Atemmechanik. Zeitschrift für die gesamte experimentelle Medizin, 66, 373.

Pattle, R. E. and Burgess, F. (1961). The lung lining film in some pathological conditions. Journal of Pathologyy and Bacteriology, 82, 315.

Phelan, P. D. and Williams, H. E. (1969). Ventilatory studies in healthy infants. Pediatric Research, 3, 425.

Radford, E. P. Jr (1957). Recent studies of mechanical properties of mammalian lungs. In Tissue Elasticity, edited by J. W. Remington, p. 177. American Physiological Society, Washington, D.C.

Salazar, E. and Knowles, J. H. (1964). An analysis of pressure-volume characteristics of the lungs. Journal of Applied Physiology, 19, 97.

Stigol, L. C., Vawter, G. F. and Mead, J. (1972). Studies on elastic recoil of the lung in a pediatric population. American Review of Respiratory Disease, 105, 552.

Zapletal, A., Misur, M., and Samanek, M. (1971). Static recoil pressure of the lungs in children. Bulletin de Physio-Pathologie Respiratoire (Nancy), 7, 139.

Requests for reprints to: Dr. D. G. Fagan, Department of Pathology, Hospital for Sick Children, 555 University Avenue, Toronto, Ontario, Canada M5G $1 \mathrm{X} 8$. 